Gut, 1989, 30, 1610-1621

Progress report

\title{
Sodium content of oral rehydration solutions: a reappraisal
}

The proliferation of commercial oral rehydration solutions (ORS), with widely varying compositions has left general practitioners and paediatricians in the United Kingdom in a state of confusion. Few remain unaware of the widespread use of oral rehydration therapy and its proven efficacy in preventing and treating dehydration associated with acute gastroenteritis.' Recommendations for the appropriate choice of oral rehydration solution particularly with regard to sodium content, however, are conflicting. The World Health Organization (WHO) continues to recommend an oral rehydration solution containing $90 \mathrm{mmol} / \mathrm{l}$ sodium regardless of the aetiology or severity of the diarrhoea or the age of the child.: WHO-ORS is used predominantly in the developing world but there has recently been some support for its use in the United Kingdom. ${ }^{3}$ In contrast, the oral rehydration solution included in the British National Formulary contains only $35 \mathrm{mmol} / \mathrm{l}$ sodium. ${ }^{+}$Oral rehydration solutions containing $45,50,60$, and $75 \mathrm{mmol} / \mathrm{l}$ sodium are also being promoted commercially (Table 1) which further complicates the issue. The purpose of this review is to consider the evidence available and define the most appropriate sodium concentration for use in the United Kingdom and other developed communities. In order to determine the appropriate concentration of a particular solute in an oral rehydration solution one must first establish its physiological function and then examine its effect in a defined clinical setting. The current rationale for the inclusion of sodium in oral rehydration solutions is two-fold: (i) to replace sodium lost in diarrhoeal stools, and (ii) to promote water absorption through glucose stimulated sodium transport. The amount of sodium required for these purposes, however, is controversial, and probably varies according to the aetiology of the diarrhoea and the age and nutritional status of the patient.

Table 1 Composition of oral rehydration solutions available in the UK

\begin{tabular}{|c|c|c|c|c|c|c|c|c|c|}
\hline Product & $B N F-O R S$ & Dioralyte & Dextrolyte & $\begin{array}{l}\text { Paedialyte } \\
\text { (maintenance) }\end{array}$ & Rehidrat & Electrolade & $\begin{array}{l}\text { Nutricia* } \\
\text { ORS }\end{array}$ & $\begin{array}{l}\text { Paedialyte } \\
\text { (rehydration) }\end{array}$ & WHO-ORS \\
\hline \multicolumn{10}{|c|}{ Composition $(\mathrm{mmol} / \mathrm{l})$} \\
\hline Sodium & 35 & 35 & 35 & 45 & 50 & 50 & 60 & 75 & 90 \\
\hline Chloride & 37 & 37 & $30 \cdot 5$ & 35 & 50 & 4() & 63 & 6.5 & 80 \\
\hline Potassium & 20 & 20 & $13 \cdot 4$ & 20 & 20 & 20 & 25 & 20 & 20 \\
\hline Lactate & () & () & $17 \cdot 7$ & 0 & () & () & () & () & () \\
\hline Bicarbonate & 18 & 18 & 0 & 0 & 20 & $29 \cdot 8$ & 0 & 0 & 0 \\
\hline Glucose & 200 & 200 & 200 & 139 & 91 & 111 & 111 & 139 & 111 \\
\hline Other ingredients & None & None & None & None & $\begin{array}{l}\text { Sucrose } \\
\text { fructose }\end{array}$ & Saccharin & None & None & None \\
\hline Osmolality & 310 & 310 & 297 & 250 & 336 & 251 & 289 & 310 & 331 \\
\hline Manufacturer & - & Rorer & Cow \& Gate & Ross & Searle & Nicholas & Nutricia & Ross & - \\
\hline
\end{tabular}

*Available in Europe. 


\section{Historical perspective}

Although parenteral fluid therapy for cholera was first suggested in 1832, oral therapy to prevent and treat dehydration was not introduced until the 1940's. Daniel Darrow, an early protagonist of oral rehydration, recommended a sodium content of $86 \mathrm{mmol} / \mathrm{l}$ on the basis of balance studies carried out in children with diarrhoea." Harrison reported the use of a solution containing $64 \mathrm{mmol} / \mathrm{l}$ sodium for mild dehydration in Baltimore City Hospital in the 1940 's and this was subsequently revised to contain 50 $\mathrm{mmol} / \mathrm{l}$ sodium and was produced commercially.? After a spate of hypernatraemic dehydration in the USA in the 1950's, however, the sodium content was further reduced to $25-30 \mathrm{mmol} / \mathrm{l} .^{*}$ In retrospect, the high incidence of hypernatraemia in children probably related to the use of high solute feeds" and to the high carbohydrate content of the oral rehydration solution, which resulted in osmotic diarrhoea thus perpetui ing dehydration.' In 1953 in adult cholera patients in Calcutta, Chatterjee showed that an oral rehydration solution containing $68 \mathrm{mmol} / \mathrm{l}$ sodium was effective when given by mouth or per rectum. "' When studying the effect of infused intragastric glucose electrolyte solutions on stool output and water and electrolyte balance in adults with cholera, Hirschhorn et al ${ }^{11}$ and Pierce et $a l^{12}$ successfully used solutions containing between 101-133 mmol/l sodium, which approximated to the sodium concentration of adult cholera stools.

On the basis of balance studies in moderate to severe dehydration in children with cholera and other infantile diarrhoeas, ${ }^{1.3}$ the WHO recommended a solution containing $90 \mathrm{mmol} / \mathrm{l}$ sodium. ${ }^{1+}$ Balance studies give a more reliable estimate of deficit than the electrolyte composition of the stool alone, as the latter fails to take into account losses in the vomitus, urine or through the respiratory tract, or the previous nutritional status. These estimates, however, may not be relevant to children in the UK with mild dehydration and diarrhoea of predominantly viral aetiology, in which the stool sodium concentration ${ }^{135^{15}-17}$ and stool volume differ considerably from those of bacterial diarrhoeas including cholera. The net sodium deficit is relatively greater for the degree of dehydration (water deficit) in cholera than in non-cholera diarrhoeas because of the higher stool sodium concentration in cholera. Stool losses in acute diarrhoea relate closely to the purging rate, which when high reduces ileal and colonic salvage of sodium. A further consideration is that pre-existing chronic malnutrition may result in reduced total body sodium and thus greater tolerance of a sodium load. It should also be stressed that the complete WHO-ORS is recommended for initial rehydration only. The addition of free water to the WHO-ORS in a ratio of two parts ORS:1 part water for maintenance therapy after rehydration, results in a fall in the sodium intake to approximately 60 $\mathrm{mmol} / \mathrm{I}^{14}$ and should minimise the risk of hypernatraemia. Undoubtedly use of the WHO-ORS in developing communities has saved the lives of millions of children of all ages ${ }^{15}$ with diarrhoea of diverse aetiologies. ${ }^{19}$ The fear of hypernatraemia, however, has deterred paediatricians in the UK and other developed communities from its use..$^{20}$ In such communities where dehydration is often mild to moderate, children have a better nutritional status and sodium losses are less, a lower sodium oral rehydration solution may be a simpler, safer but equally effective alternative. 


\section{Disturbances of sodium homeostasis in acute diarrhoea}

Alterations to serum sodium concentrations in acute diarrhoea depend on the relative losses of water and sodium in the stools (Table 2), urine and vomitus. In the majority of children, dehydration is isonatraemic. Hyponatraemic dehydration (serum sodium $<130 \mathrm{mmol} / \mathrm{l}$ ), which is more likely to develop in malnourished children with existing total body sodium deficit, ${ }^{\prime 21}: 2$ may be exacerbated by excessive consumpton of fluid with a low sodium content. ${ }^{23}$ Hypernatraemic dehydration (serum sodium $>150$ $\mathrm{mmol} / \mathrm{l}$ ) has, historically, occurred more commonly in developed communities and was often related to a high solute load, in the form of cows' milk, consumed before and during diarrhoea. ${ }^{1910}$ Its recent decline with the use of low solute, adapted cows' milk formulae and later introduction of solids into the diet supports this contention. ${ }^{2+}$ Hypernatraemia has also been associated with carbohydrate intolerance, ${ }^{2.3}$ hyperosmolar oral rehydration solutions, ${ }^{25}$ incorrect reconstitution of high sodium oral rehydration solutions, ${ }^{26}$ or use of high sodium oral rehydration solutions without additional water, especially in neonates. ${ }^{27}$ If managed inappropriately its consequences, including stroke and convulsions, may be devastating.

Children under two years are less tolerant of high sodium oral rehydration solutions because of specific physiological factors. ${ }^{.1}$ Immature renal function of infants is associated with a lower renal concentrating capacity and hence a lower maximal urine osmolality. In addition they have an impaired natriuretic response, which makes them less tolerant to high solute loads and more susceptible to sodium and water retention, particularly in states which lead to reduced vascular perfusion of the kidney. In contrast with well nourished infants in developed communities who usually receive a high protein diet, those in developing communities may be more tolerant of high solute loads as they are often malnourished with chronic electrolyte losses and are hyponatraemic before admission. ${ }^{22}$ In addition, stool sodium losses are greater in cholera, and in enteropathogenic and enterotoxigenic $E$ coli infections which are more common in these communities, than in the viral diarrhoeas which predominate in developed communities and in

Table 2 Stool electrolyte content ( $\mathrm{mmol} / \mathrm{l})$ in diarrhoea

\begin{tabular}{llccccc}
\hline Aetiology & Age $(y r)$ & $N a$ & $C l$ & $K$ & HCO $_{3}$ & Reference \\
\hline Cholera & $<5$ & 88 & 86 & 30 & 32 & 17 \\
& $<5$ & 101 & 92 & 27 & 32 & 16 \\
& $5-10$ & 107 & 88 & 26 & 30 & 13 \\
Rotavirus & Adult & 140 & 104 & 13 & 44 & 16 \\
& $<5$ & 37 & 22 & 38 & 6 & 15 \\
ETEC & $<5$ & 35 & & 26 & & 17 \\
& $<5$ & 53 & 24 & 37 & 30 & 15 \\
EPEC & $<5$ & 68 & & 25 & & 17 \\
Klebsiella sp. & $<5$ & 63 & & 24 & & 17 \\
Giardia lamblia & $<5$ & 72 & & 25 & & 17 \\
Unknown & $<5$ & 36 & & 11 & & 16 \\
(Non-cholera) & $<5$ & 56 & 25 & 55 & 14 & 17 \\
& & 68 & & 23 & & \\
\hline
\end{tabular}

ETEC, enterotoxigenic E coli: EPEC, enteropathogenic $E$ coli. 
which there are relatively greater losses of water than sodium in the stools.

Balance studies have further increased our understanding of sodium homeostasis in infancy. Aperia et al, studied sodium balance in moderately dehydrated infants given oral rehydration solutions containing $40\left(\mathrm{ORS}_{40}\right)$ or $90\left(\mathrm{ORS}_{90}\right) \mathrm{mmol} / \mathrm{l}$ sodium. ${ }^{2 \prime}$ The majority had diarrhoea of viral aetiology and the mean stool sodium concentration was $38 \mathrm{mmol} / \mathrm{l}$. All were in negative sodium balance on admission as shown by an increased renal fractional reabsorption of sodium. With both oral rehydration solutions sodium intake exceeded output throughout the $36 \mathrm{~h}$ period of rehydration. A positive sodium balance was therefore achieved with both oral rehydration solutions but was always greater with $\mathrm{ORS}_{9_{0}}$. A significant increase in the urinary fractional excretion of sodium indicating that positive sodium balance had been achieved, occurred between 12-18 h with $\mathrm{ORS}_{\left.\varphi_{0}\right)}$ and 24-36 h with $\mathrm{ORS}_{4()}$. Transient slight hypernatraemia occurred in some infants who received $\mathrm{ORS}_{9()}$ and transient slight hyponatraemia in some who received $\mathrm{ORS}_{40}$, though both groups were asymptomatic. These findings suggest that an ORS with a sodium content between the two tested might restore sodium balance while maintaining normonatraemia.

In two recent studies in Turkey" and Pakistan" this question has been pursued further. In the first balance study of oral rehydration therapy in dehydrated infants less than two months of age, 15 infants were treated with an oral rehydration solution containing $60 \mathrm{mmol} / 1$ sodium. ${ }^{31}$ All patients were in negative sodium balance on admission and sodium intake exceeded output throughout the period of oral rehydration therapy. Two hypernatraemic patients became normonatraemic but one remained hypernatraemic after treatment. Another patient who was normonatraemic on admission developed hypernatraemia during treatment. These infants retained more water and excreted less sodium in the urine compared with a group of infants over three months of age. It was concluded that immature renal function in young infants may predispose to salt and water retention and that an oral rehydration solution containing $60 \mathrm{mmol} / \mathrm{l}$ sodium was more appropriate than one containing $90 \mathrm{mmol} / \mathrm{l}$. Similar conclusions were reached in a second study of 60 moderately dehydrated infants less than two years of age who received either the WHO-ORS (sodium $90 \mathrm{mmol} / \mathrm{l}$ ) or an identical solution in which glucose was replaced by rice powder or dal moong (starch). ${ }^{31}$ Interestingly, serum sodium levels on admission were inversely correlated with age, suggesting immaturity is an important factor predisposing to hypernatraemia. Oral rehydration solutions were equally effective for rehydration, during which all patients showed a significant increase in serum sodium concentration. During maintenance therapy, however (when oral rehydration solutions and water were given using the $2: 1$ regimen), sodium concentrations tended to become normal reflecting the decreased sodium intake. Stool output was significantly less during maintenance therapy in those receiving the oral rehydration solution containing rice powder or dal moong, and there was a consequent increased capacity to correct serum sodium and sodium balance and increased weight gain in this group. Although no child developed hypernatraemia, it was concluded that renal immaturity was largely responsible for the electrolyte disturbances seen in infantile diarrhoea and that the decreased ability to produce concentrated urine increased the risk of hypertonicity with high sodium intake. 


\section{Role of sodium in oral rehydration solutions}

The rationale for inclusion of sodium in oral rehydration solutions is to replace sodium losses and to promote water absorption. Sodium (and therefore water) absorption from oral rehydration solutions in the small intestine occurs through five main mechanisms; (i) active electrogenic sodium absorption, (ii) active co-transport with glucose, amino acids, and other organic solutes, (iii) electroneutral (coupled) sodium-chloride absorption, (iv) sodium-hydrogen exchange, and (v) solvent drag.

Active electrogenic sodium absorption is highly dependent upon luminal sodium concentration. When infusing intragastric glucose electrolyte solutions containing 101,111 , and $118 \mathrm{mmol} / \mathrm{l}$ sodium in adults with cholera, Pierce et al showed that despite net water absorption and effective rehydration, net sodium balance was negative. ${ }^{2}$ Sodium loss was less, however, than in the same patients during control periods when they did not receive glucose-electrolyte solutions. Sladen and Dawson, using a human jejunal perfusion technique showed that despite net glucose and water absorption, little or no net sodium absorption occurred in the normal jejunum from glucose-electrolyte solutions containing less than $75 \mathrm{mmol} / \mathrm{l}$ sodium..$^{32}$ Similarly, Fordtran noted the influence of sodium concentration on net sodium absorption. ${ }^{33}$ Spiller et al observed that net sodium absorption only occurred in the jejunum when the luminal sodium concentration was above $133 \mathrm{mmol} / \mathrm{l}$, and showed the importance of this effect on jejunal sodium absorption from enteral feeds in man. ${ }^{34}$ In this study net sodium and water secretion occurred from feeds with low sodium content and net sodium absorption only occurred when initial sodium concentration was above $90 \mathrm{mmol} / \mathrm{l}$.

Intestinal perfusion studies in animals have shown similar results. On perfusion of normal rat jejunum with a variety of oral rehydration solutions, Lifshitz and Wapnir found sodium absorption only occurred when the oral rehydration solution sodium concentration was above $60 \mathrm{mmol} / \mathrm{l} .^{35}$ In contrast, in the cholera toxin treated secreting rat small intestine net sodium secretion occurred with all oral rehydration solutions perfused ${ }^{36}$ and by extrapolation net absorption was predicted only when the oral rehydration solution sodium concentration approached $120 \mathrm{mmol} / \mathrm{l}$. The explanation for this effect is simple. The jejunum is highly permeable, resulting in a plasmato-lumen 'leak' of sodium and an apparent diminished ability of the jejunum to absorb sodium against a concentration gradient. Thus, its luminal contents are constantly being rendered isosmotic. The question is, does net sodium secretion in the small intestine matter? Despite net small intestinal sodium secretion, glucose and water absorption sufficient to rehydrate even patients with cholera will occur from a glucose-electrolyte solution. Sodium must therefore be absorbed even if the net flux is negative. It is important to remember that absorptive and secretory processes operate simultaneously and that net solute movement represents the sum of several transport events. An oral rehydration solution sodium concentration sufficient to result in net sodium absorption is therefore unnecessary for effective rehydration. On the other hand, both sodium and water secretion occur when solutions with low sodium concentrations (23-49 $\mathrm{mmol} / \mathrm{l})$ are perfused in normal and secreting rat small intestine. ${ }^{35-38}$ In addition to being ineffective in promoting water absorption there is also evidence in animals, ${ }^{3.6}$ 
and from clinical trials ${ }^{14.34}$ that these low sodium solutions may result in hyponatraemia. It therefore seems reasonable to contemplate an oral rehydration solution sodium concentration between these two extremes, aiming to promote adequate water absorption without adversely affecting sodium status.

Finally, the role of the colon in salvaging sodium and water also deserves consideration. Defective colonic function has been confirmed in cholera ${ }^{+11}$ though less is known about its function in rotavirus infection. The immaturity of the infant colon may also be relevant to electrolyte conservation. ${ }^{+1}$

A relationship between the absorption of sodium and sugars was first suggested in 1902.+2 In vitro confirmation of the requirement of sodium ions for the active transport of glucose ${ }^{+3.3}$ was followed by numerous studies on the effect of sodium concentration on the kinetics of glucose absorption. ${ }^{+15}$ Glucose-sodium cotransport was shown in vitro, ${ }^{\text {th }}+{ }^{17}$ and was subsequently confirmed in vivo in the rat ${ }^{+18}$ and in man. ${ }^{32}{ }^{+1}$ Sodium is then actively pumped out of the cell at the basolateral membrane by the action of $\mathrm{Na}^{+} \mathrm{K}^{+}$ATPase. This creates a potential difference across the mucosa which promotes active sodium absorption. In addition to promoting active sodium absorption, glucose also promotes passive sodium absorption by solvent drag." Evidence that glucose stimulated sodium and water absorption remains intact in diarrhoea was first shown in cholera 11251 which thus provided a rational basis for the inclusion of a carbohydrate in oral rehydration solutions. Coupled sodium transport occurs with other sugars and neutral amino acids. ${ }^{+9}$ Sodium (and water) absorption is also promoted by bicarbonate and certain organic anions, notably short chain fatty acids such as acetate. We have previously reviewed the role of these substances in oral rehydration solutions.

\section{Controlled clinical trials}

Despite the wide choice of oral rehydration solutions available in the United

Table 3 Controlled trials of oral rehydration solutions with differing sodium concentrations

\begin{tabular}{|c|c|c|c|c|c|c|}
\hline Study & $\operatorname{Ref}$ & Location & $n$ & $O R S(N a)$ & Efficacy* & Complications \\
\hline Chatterjee (1978) & $(52)$ & India & 39 & $90 \vee 50$ & Similar & $\begin{array}{l}\text { Periorbital oedema/hypernatraemia with } \\
90 \mathrm{mmol} / \mathrm{l}\end{array}$ \\
\hline Santosham (1982) & (53) & USA/Panama & $146 \dagger$ & $90 \vee 50$ & Similar & Periorbital oedema with $90 \mathrm{mmol} / \mathrm{l}$ \\
\hline Santosham (1983) & (54) & Panama & $93+$ & $90 \times 50$ & Similar & None \\
\hline Sunoto $(1980)$ & $(5.5)$ & Indonesia & +2 & $90) .51$ & Similar & $\begin{array}{l}\text { Periorbital oedema, increased stool } \\
\text { frequency with } 90 \mathrm{mmol} / \mathrm{l}\end{array}$ \\
\hline Saberi (1983) & $(56)$ & Iran & 51 & 9()$\div v 58$ & Similar & $\begin{array}{l}\text { Periorbital oedema/hypernatraemia with } \\
90 \mathrm{mmol} / \mathrm{l}\end{array}$ \\
\hline Nalin (1980) & $(57)$ & Jamaica & 58 & $9(0) \div 60$ & Similar & Periorbital oedema with $90 \mathrm{mmol} / \mathrm{l}$ \\
\hline Isolauri (1985) & (59) & Finland & $101+$ & $90 \cup 60) 3$ & 5 Similar & $35 \mathrm{mmol} / 1$ less efficient \\
\hline Bhargava (1986) & (61) & India & 65 & 9()$\div v 60$ & Similar & \\
\hline Cutting (1988) & $(58)$ & UK & $269 \div$ & 9()$\cup 50 \cup 3$ & 5 Similar & Hyponatraemia with 35 and $50 \mathrm{mmol} / \mathrm{l}$ \\
\hline Islam (1982) & $(60)$ & Bangladesh & 65 & $120 \vee 60$ & Similar & Hypernatraemia with $120 \mathrm{mmol} / 1$ \\
\hline Listernick (1985) & (62) & USA & $60 \dagger$ & $60) \times 30$ & Similar & Impaired rehydration with $30 \mathrm{mmol} / \mathrm{l}$ \\
\hline Elliott (1989) & (72) & UK & $88+$ & $60 \vee 50 \vee 3$ & 5 Similar & $\begin{array}{l}\text { Carbohydrate intolerance with high } \\
\text { glucose }-35 \mathrm{mmol} / \mathrm{l} \text { oral rehydration } \\
\text { solution }\end{array}$ \\
\hline
\end{tabular}

*Rehydration and correction of plasma electrolytes: $\nmid$ Majority rotavirus; $\$$ Additional water not given with WHO-ORS. 
Kingdom, there are virtually no published controlled clinical trials assessing their safety or efficacy. Further, the rationale for their composition remains obscure and is empirical in most cases. Several workers in other developed and in developing communities have critically evaluated oral rehydration solution sodium content in controlled clinical trials some of which are outlined in Table 3.

HIGH SODIUM ORS $(90-120 \mathrm{MMOL} / \mathrm{L})$

In most studies the WHO-ORS $(90 \mathrm{mmol} / \mathrm{l}$ sodium $)$ is compared with a solution with a lower sodium content. WHO guidelines for the use of WHO-ORS specify that the complete solution should be given until the child is clinically rehydrated, after which it is alternated with water (2 volumes WHO:ORS to 1 volume water) for maintenance of hydration. Using this regimen the WHO-ORS is safe and effective for rehydration and maintenance $^{53-57}$ and corrects both hyponatraemia and hypernatraemia. ${ }^{5+57}$ In several studies, however, children receiving the WHO-ORS developed periorbital oedema suggesting sodium overload. ${ }^{5-57}$ Although there was a trend towards the development of hypernatraemia in those receiving WHO-ORS compared with a lower sodium solution, those who developed hypernatraemia were asymptomatic and the difference between groups was not statistically significant. ${ }^{53758}$ Cutting found the WHO-ORS safe and effective in mild to moderately dehydrated children in the UK with predominantly viral diarrhoea. ${ }^{59}$ Although the mean serum sodium was not significantly higher in children receiving oral rehydration solutions with 90 $\mathrm{mmol} / \mathrm{l}$ sodium than those receiving 35 or $60 \mathrm{mmol} / \mathrm{l}$, the urine sodium was significantly higher in the $90 \mathrm{mmol} / \mathrm{l}$ sodium group. This reflects the kidneys attempt to maintain homeostasis and suggests that an excessive amount of sodium is being provided by the WHO-ORS. In a study of a similar group in Finland, Isolauri found an ORS containing $60 \mathrm{mmol} / \mathrm{l}$ sodium and 144 $\mathrm{mmol} / \mathrm{l}$ glucose was as effective for correcting dehydration and sodium deficit as the WHO-ORS. ${ }^{\left({ }^{(1)}\right.}$

In one study an oral rehydration solution with $120 \mathrm{mmol} / \mathrm{l}$ sodium was used for maintenance therapy after initial intravenous rehydration and was supplemented by diluted milk." Mean serum, urine and stool sodium concentrations were significantly higher than in children receiving $60 \mathrm{mmol} / \mathrm{l}$ sodium and two developed hypernatraemia. When the osmolalities of the oral rehydration solution are compared $(401$ and $291 \mathrm{mOsmol} / \mathrm{kg}$ respectively) it is surprising that more problems were not encountered with the hyperosmolar solution. The number of children with hyponatraemia and/ or malnutrition on admission was not specified, but if high might explain the apparent 'tolerance' of such a high sodium solution.

WHO-ORS IN NEONATES

The safety of the WHO-ORS in neonates has been questioned. In a controlled trial Bhargava et al compared the use of WHO-ORS and a 60 $\mathrm{mmol} / \mathrm{l}$ ORS in neonates and concluded that when used for rehydration without additional water the WHO-ORS carries a significantly higher risk of hypernatraemia. ${ }^{27}$ Sodium intake, mean serum sodium at 8,24 , and $48 \mathrm{~h}$ after admission and urinary sodium excretion were significantly higher in this group. Further, $50 \%$ developed hypernatraemia and pedal oedema, and 
$4.5 \%$ showed excessive irritability and had convulsions. Serum sodium concentrations were normal throughout treatment in the group receiving oral rehydration solution with $60 \mathrm{mmol} / \mathrm{l}$ sodium. In a subsequent trial he compared the same two oral rehydration solutions but used the WHO-ORS in the 2:1 regimen for rehydration. Both oral rehydration solutions were effective but it was concluded that it was safe to recommend a solution containing $60 \mathrm{mmol} / \mathrm{l}$ sodium for this age group. ${ }^{62}$

MID-SODIUM ORS $(50-60 \mathrm{MMOL} / \mathrm{L})$

Oral rehydration solutions containing between $50-60 \mathrm{mmol} / \mathrm{l}$ sodium are safe, effective treatment for the dehydration and electrolyte abnormalities associated with gastroenteritis of varied aetiology $y^{5,-57,63}$ and in all age groups including neonates. ${ }^{2762}$ Asymptomatic hypernatraemia and periorbital oedema observed in many studies during treatment with the higher sodium solution did not occur. Mild asymptomatic hyponatraemia was observed in several children, however..$^{57}$ In one study weight gain was significantly greater and diarrhoea less in children receiving an oral rehydration solution containing $58 \mathrm{mmol} / \mathrm{l}$ sodium which may reflect the increased palatability of this oral rehydration solution compared with one containing more sodium. ${ }^{\text {it }}$

LOW SODIUM ORS $(30-35 \mathrm{MMOL} / \mathrm{L})$

Although solutions with low sodium and high glucose content are the most commonly used in the UK, they have only recently been subjected to controlled clinical trial ${ }^{3959}$ Results suggest that they effectively rehydrate children hospitalised with acute gastroenteritis, however, hyponatraemia may develop during treatment ${ }^{3957}$ and they may fail to correct hyponatraemia. Carbohydrate intolerance may be exacerbated by the high glucose content required to render these oral rehydration solution isotonic and the osmotic effect of unabsorbed glucose may exacerbate diarrhoea..$^{6.3}$

In summary, clinical trials suggest that when used correctly oral rehydration solutions with a sodium content of between $30-90 \mathrm{mmol} / \mathrm{l}$ are safe and effective. Exceptions include the potential for hypernatraemia if the complete WHO-ORS is used in neonates and for symptomatic hyponatraemia with prolonged use of low sodium oral rehydration solutions, particularly in malnourished children. The combination of high sodium and high glucose concentrations in oral rehydration solutions, particularly when associated with monosaccharide intolerance, is potentially very dangerous and may exacerbate dehydration and hypernatraemia. The need to alternate the WHO-ORS with water after rehydration complicates its use, particularly in the home, and the risks of incorrectly reconstituting oral rehydration solutions are probably greater with high sodium solutions.

Several uncontrolled studies also give information relating to sodium

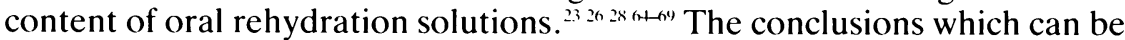
drawn from these reports are generally similar to those from the controlled studies described above.

\section{Conclusions}

Evidence accumulated worldwide over decades leaves no doubt that oral glucose-electrolyte solutions are invaluable for rehydrating, maintaining hydration and preventing dehydration in acute diarrhoea in childhood 
regardless of its aetiology and severity. Commercial production of a large variety of oral rehydration solutions whose composition cannot always be justified scientifically has caused confusion among practitioners. Introduction of the WHO-ORS to developing communities has saved millions of lives and its use in accordance with WHO recommendations should be encouraged. In developed communities such as the United Kingdom, however, where the aetiology of acute diarrhoea differs and its consequences are usually less severe, we suggest that use of the $90 \mathrm{mmol} / \mathrm{l}$ sodium solution is inappropriate and that one containing approximately 50$60 \mathrm{mmol} / \mathrm{l}$ sodium with $90-111 \mathrm{mmol} / \mathrm{l}$ glucose should be recommended.

Oral rehydration solutions containing $50-60 \mathrm{mmol} / \mathrm{l}$ sodium will safely and effectively rehydrate and maintain hydration eliminating the need for additional free water as recommended by the WHO for maintenance therapy. Hyponatraemia and hypernatraemia can both be successfully corrected and normonatraemia maintained. The sodium content is adequate to replace stool losses resulting from both viral and bacterial diarrhoeas. Unlike oral rehydration solutions with low (30-35) or high $(90 \mathrm{mmol} / \mathrm{l})$ sodium concentration, however, iatrogenic hyponatraemia and hypernatraemia respectively are unlikely to occur. In particular, the safety of the oral rehydration solution containing $50-60 \mathrm{mmol} / \mathrm{l}$ sodium in neonates and young infants with immature renal function, who are incapable of coping with increased sodium loads should be stressed. The glucose concentration needed to render the oral rehydration solution containing $50-60 \mathrm{mmol} / \mathrm{l}$ isotonic or slightly hypotonic is similar to that in WHO-ORS but approximately half that in solutions containing $30-35 \mathrm{mmol} / \mathrm{l}$ sodium. This decreases the likelihood of their causing osmotic diarrhoea with dehydration and electrolyte disturbances, especially when there is accompanying monosaccharide intolerance. Oral rehydration solutions containing 50-60 mmol/l sodium have been proven safe and effective in controlled clinical trials in which they performed favourably with the WHO-ORS, both for rehydration and correction of acidosis. In addition, perfusion studies of both the normal and secreting rat small intestine ${ }^{71}$ and the human jejunum ${ }^{71}$ suggest an oral rehydration solution containing $60 \mathrm{mmol} / \mathrm{l}$ sodium is superior with regard to water absorption than other oral rehydration solutions tested.

Errors in reconstituting oral rehydration solutions are common but are less likely to result in dangerous hypernatraemia when the original oral rehydration solution sodium concentration is below $90 \mathrm{mmol} / \mathrm{l}$. Finally, in a community such as the UK where the fall in mortality caused by gastroenteritis has been dramatic, but where it remains an important cause of morbidity and hospital admission, the aim of treatment should be simplicity and economy. Production of a single 'all purpose' physiological oral rehydration solution for rehydration and maintenance would make oral rehydration therapy in developed communities cheaper, simpler and safer and the choice for the clinician infinitely easier.

We thank Ms N Herrera and Ms N Thomas for typing the manuscript. MJGF is a Wellcome Trust Senior Lecturer and gratefully acknowledges the financial support of the Wellcome Trust. 
Depts of Gastroenterology and Child Health, St Bartholomew's Hospital, London.

Address for correspondence: Dr M J (; Farthing. Department of Gastroenterology. St Bartholomew s Hospital. West Smithfield. London FCIA $7 \mathrm{BF}$.

Accepted for publication 22 February l984.

\section{References}

1 Hirschhorn N. The treatment of acute diarrhea in children. An historical and physiological perspective. Am J Clin Nutr 1980: 33: 637-63.

2 World Health Organization/UNICEF. Oral rehydration salts. Planning, establishment and operation of production facilities. WHO/CDD/SER 1985: 85: 1-136.

3 Candy DCA. Rehydration in gastrointestinal infections. In: Black JA, ed. Paediatric emergencies. London: Butterworths \& Co, 1987: 4(03-11.

4 British National Formulary. A joint publication of the British Medical Association and the Pharmaceutical Socicty of Great Britain. 1986; 11: 290.

5 Latta T. Malignant cholera. Documents communicated by the Central Board of Health, London, relative to the treatment of cholera by the copions injection of aqueous and saline fluids into the veins. Lancet 1832: ii: 274-7.

6 Darrow DC. The retention of electrolyte during recovery from severe dehydration due to diarrhea. J Pediatr 1946; 28: 515-40.

7 Harrison HE. The treatment of diarrhea in infancy. Pediatr Clin North Am 1954; 1: 33.5-48.

8 Finberg L. Editorial. Oral therapy for dehydration in diarrheal diseases as a global problem. J Pediatr Gastroenterol Nutr 1982: 1: 3-5.

9 Colle E. Ayoub E, Raile R. Hypertonic dehydration (hypernatremia): the role of feedings high in solute. Pediatrics 1958; 22: 5-12.

10 Chatterjec HN. Control of vomiting in cholera and oral replacement of fluid. Lancet 1953; ii: 1063 .

11 Hirschhorn N, Kinzic JL. Sachar DB, et al. Decrease in net stool output in cholera during intestinal perfusion with glucose-containing solutions. $N$ Engl J Med 1968; 279: 176-81.

12 Pierce NF, Banwell JG, Mitra RC, et al. Effect of intragastric glucose-electrolyte infusion upon water and electrolyte balance in Asiatic cholera. Gastroenterology 1968; 55: 333-43.

13 Mahalanabis D. Wallace CK, Kallen RJ, Mondal A. Pierce NF. Water and electrolyte losses due to cholera in infants and small children: a recovery balance study. Pediatrics 1970; 45: 374-85.

14 WHO. A manual for the treatment of acute diarrhoea-for use by physicians and other senior health workers. WHO/CDD/SER 80; 2: Rev 1. Geneva: WHO 1984.

15 Molla AM, Rahman M, Sarker SA, Sack DA, Molla A. Stool electrolyte purging rates in cholera caused by rotavirus, enterotoxigenic $E$ coli and $V$ cholerae in children. $J$ Pediatr 1981; 98: 835-8.

16 Pierce NF. Hirschhorn N. Oral fluid - a simple weapon against dehydration in diarrhoea. WHO Chronicle 1977; 31: 87-93.

17 Deorari AK. Bhan MK. Arora NK, et al. Stool electrolyte composition in relation to etiology in acute gastroenteritis. Indian Pediatric J 1982: 19: 217-20.

18 Finberg $\mathrm{L}$. The role of oral electrolyte-glucose solutions in hydration for children international and domestic aspects. J Pediatr 1980; 96: 51-4.

19 Pizarro D, Posada G, Mohs E. Levine MM, Nalin DR. Evaluation of oral therapy for infant diarrhoca in an emergency room setting: the acute episode as an opportunity for instructing mothers in home treatment. Bull WHO 1979; 57: 983-6.

20 Harrison HE. Finberg L. Hypernatremic dehydration. Pediatr Clin North Am 1964: 11: 955-61.

21 Bart KJ, Finberg L. Single solution for oral therapy of diarrhoca. Lancet 1976; ii: 633-4.

22 Patra FC, Mahalanabis D, Jalan KN, Sen A, Banerjec P. Is oral rice electrolyte solution superior to glucose electrolyte solution in infantile diarrhoca? Arch Dis Child 1982; 57: $910-2$.

23 Hirschhorn N, McCarthy BJ, Ranney B, et al. Ad libitum oral glucose electrolyte therapy for acute diarrhea in Apache children. J Pediatr 1973; 83: 562-71.

24 Manuel PD, Walker-Smith JA. Decline of hypernatracmia as a problem in gastroenteritis. Arch Dis Child 1980; 55: 124-7. 
25 Sandhu BK, Jones BJM, Brook CGD, Silk DBA. Oral rehydration in acute infantile diarrhoea with a glucose-polymer electrolyte solution. Arch Dis Child 1982; 57: 152-60).

26 Cleary TG, Cleary KR, Dupont HL, et al. The relationship of oral rehydration solution to hypernatraemia in infantile diarrhea. J Pediatr 1981; 99: 739-41.

27 Bhargava SK. Sachdev HPS. Das Gupta B. Daral TS. Singh HP. Mohan M. Oral rehydration of neonates and young infants with dehydrating diarrhea: comparison of low and standard sodium content in oral rehydration solutions. J Pediatr Gastroenterol Nutr 1984: 3: 500-5.

28 Hirschhorn N. Cash RA. Woodward WE. Spivey GH. Oral fluid therapy of Apache children with acute infectious diarrhoea. Lancet 1972: ii: 15-8.

29 Aperia A. Marin L, Zetterstrom R, et al. Salt and water homeostasis during oral rehydration therapy. J Pediatr 1983; 103: 364-9.

30 Marin L, Saner G, Sokucu S, Gunoz H. Neyzi O, Zetterstrom R. Oral rehydration therapy in neonates and young infants with infectious diarrhoea. Acta Pediatr Scand 1987: 76: $431-7$.

31 Murtaza A. Zulfiqar I, Khan SR, Lindblad BS. Aperia A. Regulation of serum sodium in dehydrated and orally rehydrated infants. Influence of age and of purging rates. Acta Paediatr Scand 1987; 76: 424-30.

32 Sladen GE, Dawson AM. Interrelationships between the absorptions of glucose, sodium and water by the normal human jejunum. J Clin Invest 1975; 55: 728-37.

33 Fordtran JS. The mechanism of sodium absorption in the human small intestine. J Clin Invest 1968; 47: 884-900.

34 Spiller RC, Jones BJM, Silk DBA. Jejunal water and electrolyte absorption from two proprietary enteral feeds in man: importance of sodium content. Gut 1987; 28: 681-7.

35 Lifshitz F, Wapnir RA. Oral hydration solutions: experimental optimization of water and sodium absorption. J Pediatr 1985; 106: 388-9.

36 Rolston DDK. Borodo MM, Kelly MJ, Dawson AM, Farthing MJG. Efficacy of oral rehydration solutions in a rat model of secretory diarrhea. J Pediatr Gastroenterol Nutr 1987; 6: 624-30.

37 Elliott EJ, Watson AJM, Walker-Smith JA, Farthing MJG. Effect of bicarbonate on efficacy of oral rehydration therapy: studies in an experimental model of secretory diarrhoca. Gut 1988; 29: 1052-7.

38 Wapnir RA, Lifshitz F. Osmolality and solute concentration - their relationship with oral hydration solution effectiveness: an experimental assessment. Pediat Res 1985: 19: 894-8.

39 Elliott EJ, Armitstead JCM, Farthing MJG, Walker-Smith JA. Oral rehydration therapy without bicarbonate for prevention and treatment of dehydration: a double-blind controlled trial. Aliment Pharmacol Therapy 1988; 2: 253-63.

40 Speclman P, Butler T, Kabir I, Ali A, Banwell J. Colonic dysfunction during cholera infection. Gastroenterology 1986; 91: 1164-70.

41 Jenkins HR, Milla PJ. The development of colonic transport mechanisms in early life: evidence for reduced anion exchange. Early Hum Dev 1988; 16: 213-8.

42 Reid EW. Intestinal absorption of solutions. J Physiol 19(2); 28: 241-56.

43 Riklis E. Quastel JH. Effects of cations on sugar absorption by isolated surviving guinca pig intestine. Can J Biochem Physiol 1958; 36: 347-62.

44 Csaky TS. A possible link between active transport of electrolytes and non-electrolytes. Fed Proc (Baltimore) 1963; 22: 3-7.

45 Crane RK. Sodium-dependent transport in the intestine and other animal tissues. Fed Proc 1965; 24: 1000-6.

46 Schultz SG, Zalusky R. Ion transport in isolated rabbit ileum II. The interaction between active sodium and active sugar transport. J Gen Physiol 1964; 47: 1043-59.

47 Barry RJC, Smyth DH, Wright EM. Short circuit current and solute transport by rat jejunum. J Physiol 1965; 181: 410-31.

48 Levinson RA. Scheld HP. Absorption of sodium chloride, water and simple sugars in rat small intestine. Am J Physiol 1966; 211: 939-42.

49 Schultz SG. Sodium-coupled solute transport of small intestine: a status report. $A m J$ Physiol 1977; 223: 249-54.

50 Fordtran JS. Stimulation of active and passive sodium absorption by sugars in the human jejunum. J Clin Invest 1975; 55: 728-37.

51 Phillips RA. Water and electrolyte losses in cholera. Fed Proc (Balti) 1964; 23: 705-9.

52 Elliott EJ, Walker-Smith JA, Farthing MJG. The role of bicarbonate and base precursors in the treatment of acute gastroenteritis. Arch Dis Child 1987; 62: 91-5.

53 Chatterjee A. Mahalanabis D. Jalan KN, et al. Oral rehydration in infantile diarrhoca. Arch Dis Child 1978; 53: 284-9. 
54 Santosham M, Daum RS, Dillman L, et al. Oral rehydration therapy of infantile diarrhea. N Engl J Med 1982; 306: 1070-6.

55 Santosham M, Carrera E, Sack B. Oral rehydration therapy in well nourished ambulatory children. Am J Trop Med Hyg 1983; 32: 804-8.

56 Sunoto, Suharyono, Suryono Wibowo, Sumarso. Oral rehydration solution. An appropriate formula for acute infantile diarrhea. Pcediatr Indones 1980; 20: 20.5-1.5.

57 Saberi MS. Assace M. Oral hydration of diarrhoeal dehydration. Comparison of high and low sodium concentration in rehydration solutions. Acta Paediatr Scand 1983; 72: 167-70).

58 Nalin DR, Harland E, Ramlal A, et al. Comparison of low and high sodium and potassium content in oral rehydration solutions. J Pediatr 1980; 97: 848-53.

59 Cutting WAM. Belton NR. Gray JA. et al. The safety and efficacy of three oral rehydration solutions for children with diarrhoea. Acta Paediatr Scand 1989. 78: 25.3-8.

6) Isolauri E. Evaluation of an oral rehydration solution with $\mathrm{Na}+60 \mathrm{mmol} / \mathrm{l}$ in infants hospitalized for acute diarrhoea or treated as outpatients. Acta Paediatr Scand 1985: 74: 643-9.

61 Islam MR. Bardhan PK. Rahman MM. A comparison of oral replacement solutions containing sodium in concentrations of $120 \mathrm{mmol} / \mathrm{l}$ and $60 \mathrm{mmol} / \mathrm{l}$ in paediatric diarrhoca. Indian J Pediatr 1982: 49: 349-95.

62 Bhargava SK, Sachdev HPS, Das Gupta B, Man Mohan, Singh HP. Daral TS. Oral therapy of neonates and young infants with World Health Organization Rehydration Packets: a controlled trial of two sets of instructions. J Pediatr Gastroenterol Nutr 1986: 5: 416-22.

6.3 Listernick R. Zieserl E. Davis AT. Oral glucose-electrolyte solutions as maintenance therapy of acute diarrhea. Am J Dis Child 1985; 139: 571-4.

64 Abdalla S. Henry N, El Essaily M. Nasser S. Hirschhorn N. Oral rehydration for the lowbirthweight baby with diarrhoca. Lancet 1984; ii: 818-9.

6.5 Sack DA. Islam R. Brown KH, et al. Oral therapy in children with cholera: a comparison of sucrose and glucose electrolyte solutions. J Pediatr 1980; 96: 20-5.

66 Pizarro D. Posada G, Mata L. Nalin D. Oral rehydration of neonates with dehydrating diarrhocas. Lancet 1979; ii: 1209-10.

67 Pizarro D, Posada G, Mata L. Treatment of 242 neonates with dehydrating diarrhea with an oral glucose-electrolyte solution. J Pediatr 1983; 102: 153-6.

68 Blum D, Brasscur V, Kahn A. Brachet E. Safe oral rehydration of hypertonic dehydration. J Pediatr Gastroenterol Nutr 1986: 5: 232-5.

69 Hutchins P. Wilson C, Manly JAE. Walker-Smith HA. Oral solutions for infantile gastroenteritis - variations in composition. Arch Dis Child 1980; 55: 616-8.

70 Elliott EJ, Walker-Smith JA. Farthing MJG. Relationship between glucose and sodium in oral rehydration solutions: studies in a model of secretory diarrhoca. Pediatr Res 1986; 20: 690 .

71 Elliott EJ, Hunt JB, Watson AJM, Walker-Smith JA, Farthing MJG. Oral rehydration solutions: assessment in human and animal models of intestinal perfusion. Pediatr Res 1987: 22: 108 .

72 Elliott EJ. Da Cunha Ferreira RMC. Cameron D, Farthing MJG. Walker-Smith JA. Evaluation of three oral rehydration solutions designed for use in developed countries. Aliment Pharmacol Therap 1989. 3: 233-43. 